\title{
Beacon Hill School
}

\section{by David Harley}

BEACON HILL SCHOOL has been the subject of much flippancy and misunderstanding over the years. Typical of the levity with which it has been viewed is the following verse:

His formal education done,

He scorned the lesser Kinds of Fun

And started a Progressive School

Untrammelled by Pedantic Rule

Combining Roses round the Trellis

With Interludes from Havelock Ellis.

The most widely publicized example, however, is that of the little girl and the rector. As the tale goes, the local rector upon ringing the doorbell at Telegraph House was greeted by a little girl who was quite naked. "Good God!" he exclaimed. "There is no God!", the child replied while slamming the door. ${ }^{2}$ Yet in common with other such apocryphal tales, this one has as little claim to reality as the doorbell which Telegraph House did not have. ${ }^{3}$ Misunderstandings and misrepresentations abound. It is surprising to find that despite the amount of research done on the various aspects of Bertrand Russell's life and thought, there has not been a single study to date devoted specifically to his contribution in the running of Beacon Hill School.

For a potential researcher, such a gap provides both advantages and disadvantages-advantages in that he is dealing with totally new material, disadvantages in that there are usually reasons why others have not attempted the task. When I began a systematic investigation

1 David Low, Low's Company: Fifty Portraits, with Verses by Helen Spalding and L.A.G. Strong (London: Methuen, 1952), p. 96.

2 Alan Wood Bertrand Russell: The Passionate Sceptic (London: Allen \& Unwin, 1957), p. 157.

${ }^{3}$ Katharine Tait, My Father Bertrand Russell (London: Gollancz, 1976), p. 70. 
of Beacon Hill three years ago, the Russell Archives at McMaster University, though rich in other resources, contained little of significance regarding the school in files that were open to researchers. There was in fact no existing collection of primary source material upon which such a study could be based. With the help of the Russell Archivist and various members and friends of the Russell family, a system of networking brought to light some 500 letters, documents and tape-recordings. The response on the part of those connected with the school has been remarkable. Such a reaction has resulted not only from a genuine kindliness and generosity on their part, but also from a collective belief that Beacon Hill was a worthwhile venture which had, and has today, a value for those interested in directing education towards a more humane world.

Such faith in the merits of Beacon Hill School contrasts sharply with that of Russell himself, who offered no encouragement whatever to those interested in the school. Indeed, he actively discouraged the pursuit of this line of inquiry. Joe Park, for example, the author of Bertrand Russell on Education, tried in vain to learn more about this topic from him:

$\mathrm{He}$ [Russell] made it quite plain that he did not wish the present writer to go into the subject of Beacon Hill: 'It wasn't at all the sort of place I had imagined it would be!' Since Russell feels that Galileo's father's methods of teaching his son mathematics, by denying him access to books on the subject, was a most successful method of teaching, perhaps he was only trying to encourage an investigation into the Beacon Hill School? One wonders! 4

However, in the fifteen years that have elapsed since the publication of Park's book, this gap in Russell scholarship has remained. One can only say that if indeed Russell was attempting to use reverse psychology in order to evoke interest, the desired result has been a long time in coming.

The purpose of the present paper is to dispel a few of the more common misunderstandings surrounding the operation of Beacon Hill while mentioning in passing some of the interesting facts which have emerged during the course of this research. Some very interesting aspects which deserve fuller treatment have been omitted. It should be emphasized that much of this information is based upon documents now in the possession of the Russell Archives. This

${ }^{4}$ Joe Park, Bertrand Russell on Education (London: Allen \& Unwin, 1964), pp. 122-3. material has been either deposited with the permission of those who forwarded it or purchased outright by McMaster University in cases where individuals were willing to part with originals. I should add also that the following is confined to statements pertaining to the school prior to the separation between Bertrand and Dora Russell in 1932.

As Russell has written in the second volume of his Autobiography, Beacon Hill School came into being as a result of a joint decision on his and Dora's part to found a school adequate to the needs of their children, John and Kate. Having looked about at the varieties of educational methods available, they could see nothing that was in complete accordance with their own ideals and theories. But contrary to the prevalent belief that Russell's interest in education arose only because of the advent of his children, it is interesting to note that he considered the possibility of starting up a school on at least one prior occasion. In an early letter to his future first wife, Russell wrote:

I wish we were going to have children, if only to give them a sensible education in matters of sex-I should almost like to start a co-educational school for the purpose of applying my theories ... only nobody would come to it. ${ }^{5}$

Indeed, one of the more pervasive myths surrounding Russell's educational thought is that it emerged only after he and Dora had children. Few realize that his interest in education substantially predates his second marriage. Witness, for example, his concern with his own early education in Chapter I of the Autobiography. From the middle of the First War onwards he was deeply occupied with the role of education in the production of a better society. To this end, he devoted an entire chapter of Principles of Social Reconstruction to making his views known. The founding, therefore, of Beacon Hill must be understood as an event whose origins go far back in Russell's intellectual and emotional development.

American readers first learned of the inception of the school in The Nation of 16 March 1927, where, in an advertisement addressed to "MODERN PARENTS", the Russells offered "... to educate, from babyhood to university age, in ideal country surroundings (with large wooded private grounds), a group of boys and girls, who, in September, 1927, when the school opens, are between the ages of two and seven years." The timely and successful publication of On

${ }^{5}$ Russell to Alys Pearsall Smith, 12 Sept. 1894 (Russell Archives; original in the possession of B. Halpern). 
Education: Especially in Early Childhood ${ }^{6}$ in the previous year had announced to the world a detailed account of what Russell thought the lines of educational reform should be. Parents who had been sympathetic to these ideas were now offered the opportunity to have these theories put into practice with their own children.

In the original prospectus (only recently uncovered) issued by the Russells, interested parties could learn that Beacon Hill had "... been planned to meet the needs of parents who desire a break with traditional educational methods, not only during the early years of a child's life, but throughout education."7 Reading on, they would find that the Russells would "attempt to combine physical and psychological care in the manner suggested by modern knowledge of the growth of personality", that "every attempt will be made to avoid or to dispel the anxieties and nervousnesses to which developing children are liable", and that the school was designed for "normal children of average health and intelligence." Emphasis was to be placed upon physical and mental health. Open air activities would be encouraged. The ample grounds would give children every opportunity for "running wild as in the old-fashioned large family". Basic educational methods would be run along the lines of Margaret McMillan, Maria Montessori and Friedrich Froebel, giving to each child both a good general background as well as encouragement of individual abilities. No deliberate distinction would be made between boys and girls while some domestic knowledge and practice would be encouraged in both sexes. Aesthetic development was to be fostered through sense training, dancing, various forms of plastic expression, music, singing and co-operative plays. In all such matters, children were to be encouraged to learn by themselves as opposed to being taught. Education was, therefore, to be regarded as essentially an active rather than a passive process.

Intellectual development, according to the prospectus, was to be given considerable emphasis. Interest would be aroused by free discussion in later years through "... argument on every arguable question". In this regard, complete freedom of speech was to be the rule. Any question posed by the child was to be answered frankly and truthfully regardless of the age of the child or the subject matter of the question. Despite this unorthodox environment, adequate preparation necessary for examinations and university scholarships was to be provided for the older children:
We shall hope to make the definite instruction as thorough as in the most efficient existing schools, but, we believe, with less strain to the pupils. Subject to the limitations set by examinations, we shall aim at somewhat different outlook towards knowledge from that which is customary in schools.

The teaching of history would emphasize an awareness of the history of man in the same vein as H. G. Wells' Outline of History rather than on the narrow political or military exploits of one country, and in fact Wells' work was employed as a text-book by the Russells. Classics were to be held to a minimum while the main emphasis would be upon science and modern humanities. In all such matters, individual initiative and curiosity were to provide the main thrust for learning-not authority, discipline and drill. Knowledge was to be presented not "as mere knowledge, but as an instrument of progress, the value of which is shown by bringing it into relation with the needs of the world." An education at Beacon Hill was not designed to produce "... listless intellectuals, but young men and women filled with constructive hopefulness, conscious that there are great things to be done in the world, and possessed of the skill required for taking their part."

However, if the potential clients were impressed by the aspirations of this venture, they would have been equally impressed by the setting within which it was to take place. A visiting parent in 1928 would stay with the older children at Battine House, a building rented by the Russells and located a short distance from the school in East Marden, Sussex. Here Sylvia Pankhurst would write a book while her son Richard (who is reported to have been the only male who could stand up to that suffragette) attended Beacon Hill as a day student. Guests were attended by uniformed maids. Tea could be served in bed in the morning while a total of four meals a day was provided. A chauffeur employed by the Russells would pick up guests and drive them to the school. ${ }^{8}$ After several miles, they would come upon the long entrance surrounded by copper beeches which wound for a further mile to the top of the hill. There, situated among 250 acres of virgin forest on the South Downs, and some 620 feet above sea level, stood Telegraph House.

The building itself was large, claiming the then modern conveniences of electric light and central heating. Near it were a lawn tennis court and a small building used for science classes. The large tower 
10 Russell, nos. 35-6 (Autumn-Winter 1979-80)

which dominated the view of Telegraph House marked Bertrand Russell's study. In that room with its cream walls and soft blue silk Chinese carpets, Russell was to write the many articles which went towards sustaining the school's existence. Here one would see an extensive library, a marble bust of Voltaire, numerous Chinese bronzes and ivories, pictures of Russell's temporal and spiritual ancestors and his brother's old brass telescope with which he inspected the view. Looking from these windows, one could see across the downs from Leith Hill and Hindhead to the sea and the Isle of Wight. Of this room Russell was to later write that he had never seen one with a more beautiful view. ${ }^{9}$ Here Russell was to teach history to young and extremely enthusiastic classes. ${ }^{10}$

The interior of the house was spacious, open, and simply but gaily furnished. Bedrooms for the children each contained two or three single beds painted in various bright colours and with curtains to match. Even the chamber pots were chosen in complementary colours. Everything indicated a belief in simplicity, efficiency and utility. "

The support staff included a cook, housekeeper, three maids, two chauffeurs and a gardener. The teaching staff consisted of a matron, assistant matron, science, art and language instructors, a visiting part-time music teacher, a doctor who came up to the school regularly to give periodical examinations of the children, and finally Russell's private secretary. When the school began, there were twelve boarders and five day pupils. At a yearly tuition fee of 150 pounds for the former and 50 pounds for the latter, it should be of little surprise that the school lost money. During its first twelve months of operation, Beacon Hill ran at a net loss of 1847 pounds, a sum which was made up out of Russell's private earnings. ${ }^{12}$ In addition to the fact that, as he himself admits, Russell was a poor administrator, fees were often late or never forthcoming. Refusing to increase the number of children for fear of a reduction in educational quality, or to increase the tuition with the result that average parents would not be able to afford the school, Russell wrote a number of pleas for added support to some of the wealthier parents. Despite the relinquishing of Battine House in 1931 and the fact that the teaching staff were prepared to work for about one-third regular salary,

\footnotetext{
${ }^{9}$ The Autobiography of Bertrand Russell, II (London: Allen \& Unwin, 1968), p. 153.

10 Tait, p. 71 .

"Letter to author from parent dated 18 July 1977.

12 Ronald W. Clark, The Life of Bertrand Russell (London: Cape/Weidenfeld and Nicolson, 1975), p. 427.
}

Beacon Hill remained an expensive task requiring the untiring efforts of Russell and Dora to keep it afloat.

Wells' novel, Tono-Bungay, describes a scene from a Victorian childhood as follows:

I sat among these people on a high, hard early Gregorian chair, trying to exist, like a feeble seedling amidst great rocks, and my mother sat with an eye upon me, resolute to suppress the slightest manifestation of vitality. ${ }^{13}$

It was precisely this atmosphere which Beacon Hill sought not to create. Children were to be spared the crushing encroachment of the great rocks of respectability. To this end, the Russells encouraged complete freedom of speech. One parent was a little surprised to have her daughter during the course of a parent's day visit point to a small heap left by one of the numerous rabbits which inhabited the woods and proudly exclaim a four-letter description. ${ }^{14}$ But such was the price of freedom! Everything possible was done to see that there would be an absolute minimum number of social taboos interfering with the children's healthy development, sexual and otherwise.

Russell's concern with this matter is clearly shown in a letter of July 1931 to a parent. In an attached sheet he describes verbatim a conversation which he had overheard among the children:

Mike: Damn!

Frances: My mother hates me to use that word.

Jane: So does mine.

Mike: So does mine, but I do it. (Giggles).

Frances: Does yours, Jason? (Jason nods. Frances asks again.)

Jason: (crossly) Yes. Didn't you see me nod?

Frances: My Mother says it isn't a correct word.

Betty: Why isn't it a correct word?

Frances: What? I don't know.

Pause ... then five minutes later Frances revives again.

Frances: She says it doesn't sound nice.

Mike: Pouff! It does ... quite nice.

Jason: (Jason speaks firmly as if to put an end to all doubt on the matter) It's a swear word.

Mike: (Unmoved by Jason's remark) What do you mean ... correct?

${ }^{13}$ Tono-Bungay (New York: Modern Library, 1935), pp. 16-17.

${ }^{14}$ Letter to author from parent dated 19 April 1977. 
Frances: Not a proper word. 15

Russell concludes from this that, "It shows how hard it is to safeguard children from foolish forms of moral prohibition." For Russell, complete freedom of speech was of seminal importance:

When children are left free as regards their language, they say from time to time such things as Freudian text-books assert that they must be thinking, but being able to express their thoughts freely, they are not obliged to give them some fantastic form and become to that extent out of touch with reality. ${ }^{16}$

And again:

We think it is rather a mistake to give people an expensive education in concealment resulting in nervous disorders, and then give them an expensive re-education to break down the concealment and possibly cure the nervous disorders.

As a result of this methodology, the children at Beacon Hill were quite direct and said pretty much what they thought. At the same time, they knew that "their school was a special place and that their speech, customs, and dress were not acceptable everywhere." 17 Of course, on occasion, those too young to be prudent were a potential source of concern. As one teacher recalled:

I also remember one story about her (Kate) and a little friend making off for London (they were about 8 years old) taking with them their dancing shoes and some flowers to sell. They were found by the local Vicar. B. Russell was worried when he heard because he felt that their languagemight not go down well in the vicarage. ${ }^{18}$

After the children were returned, Russell kept them in bed for a time, claiming that their legs were tired and needed rest.

All matters of discipline were carried out with typical Russellian subtlety. Another incident was remembered by an ex-teacher:

I was called out by B.R. to the front of the house where there was a very high tree. At the top was Frank. Says B. R. "Now Frank, Miss "So-and-so" has seen you. Mr. "So-and-so" has

\footnotetext{
15 " Opinions on Swearing", n.d. [1930] (Russell Archives). Included in Jason Harvey file ("Recent Acquisitions").

16 "Free Speech in Childhood", New Statesman and Nation, I (30 May 1931), 486.

${ }^{17}$ Letter to author from Beacon Hill teacher dated 19 April 1977.

${ }^{18}$ Letter to author from Beacon Hill teacher dated 10 July 1977.
}

seen you, the gardener has seen you, various visiting teachers have seen you (named) so you need not go up again!!" As far as I know he never did! 19

When reason faltered, the boredom of being sent to bed rarely did. Interviewed by G. F. Hughes, Russell recalled:

... a little girl had set fire to the gorse round the house ... and

this after she had been warned against the disturbing practice.

She was sent to bed, and felt very bored. Could she get up now?

"But then," objected Mr. Russell, "you might do it again."

"Yes", she agreed, "that's true."

So for a while she remained in bed. But then after a promise she at last rose. ${ }^{20}$

During the same interview, Russell remembered the time when a child had drawn a large picture of a tiger pursuing its prey on one of the classroom walls. The interviewer mentioned to him what probably would have been his fate in a conventional school. "'Quite so,' said Mr. Russell. 'He would have been cowed for the time, and would have behaved himself; but when he grew up he would have squared his account with the world.'"

At no time was a child told to do something without being given a good reason. Such restrictions were limited to matters pertaining to health (about which no freedom was allowed), safety, and the treatment of other children. Attendance at classes was not mandatory. However, every effort was made to ensure that the child who did not would be so bored as to gladly return to classes. "Freedom," Russell wrote, "in education as in other things, must be a matter of degree. Some freedoms can not be tolerated." $21 \mathrm{He}$ continued:

... one who advocates freedom in education cannot mean that children should do exactly as they please all day long. An element of discipline and authority must exist; the question is as to the amount of it, and the way it is to be exercised.

Indeed, one of the most enduring myths about Beacon Hill is that it was a place of complete "freedom". As a result, the educational methods practised there have often been confused with the more radical approach of A.S. Neill's Summerhill about which so much

${ }^{19}$ Ibid.

20" "Good Adults-Not Good Children: Bertrand Russell on the Teacher's Job", Senior Teacher's World, 48 (22 May 1935), 297.

21 "Freedom or Authority in Education", Century Magazine, 109 (Dec. 1924), 184. 
has been written. Yet methods of "free" education differed greatly. Responding to a critical attack in 1930 upon precisely this issue of the amount of freedom at the school, Russell wrote that the critic "... appears to think that the principles upon which we run our school can be described as-'Back-to-Nature-Don't-discipline-the-Child theories.' It may possibly interest you to know that self-discipline, and more particularly intellectual discipline, is one of the main things taught in our school." 22 Although it is true that by way of comparison Beacon Hill was a "free" school, it was not a freedom without a carefully thought out structure. Recent investigation has turned up the fact that the school even issued report cards. One of these dating from 1930 contains the following headings: Height, Weight, Physical Report, Reading, Writing, Arithmetic, History, Geography, French, English Literature and Grammar, German, Science, Hand and Craft Work, Eurythmics and Music, Music (again), and General Psychology. ${ }^{23}$

As early as 1917 Russell had classified educational theories in accordance with the kinds of people they sought to produce and had argued that the general principle of educational reform should be to educate others as you would have liked to have been educated yourself. ${ }^{24}$ To this extent, Beacon Hill did aim at producing a certain kind of person and to this end the limits of freedom were carefully defined. Following Rousseau's dictum that plants are fashioned by cultivation, man by education, ${ }^{25}$ education was for both the Russells a means of bringing constructive adults into the world who would confront and ultimately solve the problems of the future. Such individuals would be characterized by vitality, courage, sensitiveness and intelligence. Freedom was to be employed to foster and develop these qualities. Where it did not, Bertrand Russell was perfectly willing to advocate increased discipline. There exists, for example, a remarkable letter sent by him to the parent of a particularly troublesome child:

$\ldots$ and for the good of the school it will be necessary not to keep Jason beyond the end of this term. He needs, in my opinion, quite other methods than ours. He should be, I think, among boys only, and with only men teachers, and subjected to very strict discipline where rebellion never pays. Moreover he

22 "The Bertrand Russell School", Time and Tide, 11 (3 Jan. 1930), 12

${ }^{23}$ Report Card dated 5 April 1930, Jason Harvey file (Russell Archives).

24 "Self-Discipline and Self-Government", Herald of the Star, 6 (Sept. 1917), 484

${ }^{25}$ Emile (London: Dent, 1966), p. 6. should be where there are boys bigger than himself. Here he is too much of a king. You can imagine how reluctantly I have come to this conclusion; it is more mine than Dora's. ${ }^{26}$

In another letter pertaining to the same matter but dated one month later Russell writes: "I feel that our methods are not suited to him, and that he needs either less discipline than we have here or else a great deal more." 27 Such remarks suggest that Russell saw freedom as a means to an end in education rather than as an end in itself. As Katharine Tait has written:

They never imagined that undirected children would eat what they should, sleep when they should, learn all that they need to know. But they believed that children would be more likely to acquire proper mental and physical habits through adult encouragement than through adult command. ${ }^{28}$

The Russells were careful to employ freedom so that it fostered healthy independent growth. Their ideal was to create autonomous individuals with the capacity to stand alone and also with the compassion to help build a society which would promote creative rather than destructive ends.

The last major misunderstanding with which I would like to deal is that the school is generally thought and believed to be a failure. Such a reaction is hardly surprising in that almost every reference to Beacon Hill states either implicitly or explicitly that this is so. Leggett, for example, in his 1949 pictorial biography of Russell writes: "The Russells' school at Beacon Hill was not a success." 29 In the remaining three sentences devoted to these five years of Russell's life, he goes on to say that this resulted from the fact that Russell was not a good organizer while his wife was not interested in the domestic aspects of the school. Thus the resulting waste and expense were not covered by the nominal fees charged to parents. Alan Wood writes that the school failed "for reasons which had nothing to do with the rightness or wrongness of his ideas." 30 The general tone of failure is again presented in Russell's own Autobiography and perpetuated in Ronald Clark's The Life of Bertrand Russell. In each case we find that Beacon Hill failed and that this fact was now entered the great slumber of decided opinion.

\footnotetext{
${ }^{26}$ Russell to Dorothy Reagan, 11 March 1930, Jason Harvey file (Russell Archives).

${ }^{27}$ Russell to Dorothy Reagan, 28 April 1930.

${ }^{28}$ Tait, p. 73.

${ }^{29}$ H. W. Leggett, Bertrand Russell O.M. (New York: Philosophical Library, 1950), p. 35
}

${ }^{30}$ Bertrand Russell: The Passionate Sceptic, p. 151. 


\section{Russell, nos. 35-6 (Autumn-Winter 1979-80)}

In the course of this research, ample evidence has come to light to deny this contention. The school may not have been a success on the scale which Russell would have liked. It did not usher in the new social order or produce the elite corps of the new age. But throughout my research, I have not encountered a single individual connected with the school who thought that it was a failure. Indeed, more than one correspondent registered his surprise with Russell's gloomy verdict. Curiously, Russell himself did not always feel so disillusioned about the venture. In May of 1931 an article appeared by Russell in which he depicted a radically different picture:

At Beacon Hill School, on the South Downs, my wife and I are putting into practice our theories of education. We are now at the end of the fourth year, and are beginning to be in a position to say something of results ... I firmly believe that our methods enable a child to acquire knowledge without losing the joy of life and to become scientific without ceasing to be spontaneous. I hoped that this might be the case when we founded the school, and my hopes are now confirmed by nearly four years' experience. ${ }^{31}$

It is startling to find this enthusiastic endorsement of a school which Russell took unusual steps to dissociate himself from in later years.

In conclusion, my research indicates that much of the bad press to which Beacon Hill has been subjected over the years has come from two sources. The first is that the school was misrepresented from the very beginning by the press whose desire to thrill and titillate their audiences resulted in half-truths and exaggerations. The second is that the divorce between Russell and Dora was a mutually painful experience which seems to have clouded Russell's judgment as to how much he and Dora had achieved. In order to secure some custody of his children, and have them sent to Dartington Hall, Russell actively sought to denigrate Beacon Hill School. During this process he succeeded in convincing himself that his marriage and the product of that partnership were failures of equal standing. It can only be viewed as regrettable that Beacon Hill has not even to the present day freed itself from the taint of those painful memories and misrepresentations.

Department of History and Philosophy of Education

Ontario Institute for Studies in Education

University of Toronto

31 "Free Speech in Childhood", pp. 486-8. 